\title{
Abstracts of contributions presented in the VII. International Conference on the Conservation of the Eastern Imperial Eagle, Bratislava, Slovakia, 2013
}

\author{
Abstrakty príspevkov prezentovaných na VII. Medzinárodnej konferencii o ochrane orla \\ král'ovského, Bratislava, Slovensko, 2013
}

\section{Edited by Lucia DEUTSCHOVÁ \& Zuzana GUZIOVÁ}

VII. International Conference on the Conservation of the Eastern Imperial Eagle (Aquila heliaca) was held on October 2-5, 2013 in Barónka hotel in Bratislava, Slovakia and it was organised by Raptor Protection of Slovakia (RPS) in cooperation with the Czech Society for Ornithology and MME/BirdLife Hungary, under the auspices of the Ministry of Environment, supported by the International Visegrad Fund. Results of 43 experts from ten countries, including three countries of Visegrad region (Slovakia, Czech Republic and Hungary) were presented in 20 presentations and five posters. Six contributions are published in Slovak Raptor Journal volume 8 , issue 1 (2014) as full papers, further twelve contributions are published here as conference abstracts.

Key words: imperial eagle conference, Aquila heliaca, Visegrad region.

Lucia Deutschová, Zuzana Guziová, Raptor Protection of Slovakia, Kuklovská 5, 84104 Bratislava, Slovakia. E-mail: deutschova@dravce.sk,guziova@dravce.sk.

Acknowledgements: The conference was held under the auspices of the Ministry of Environment, with the financial support from the International Visegrad Fund and with expert support of MME/BirdLife Hungary and Czech Society for Ornithology. The organizers would like to thank to everyone who contributed to the organisation and implementation of the conference and to all of the participants for valuable data and experience. Detailed information about the conference can be found at www.dravce.sk/ie.

\section{Abstracts}

Status of the eastern imperial eagle in Visegrad Region

Stav orla král’ovského vo Višegrádskom regióne

\section{Jozef CHAVKO, Lucia DEUTSCHOVÁ, Márton HORVÁTH \& David HORAL}

Visegrad countries host a significant part of the European population of the eastern imperial eagle. The species regularly breeds in Hungary, Slovakia and the Czech Republic. In Poland it is considered a vagrant species. The population has shown an increasing trend in recent years. In the period 2008-2013 it has increased by about $145 \%$ from about 140 breeding pairs in 2008 to ca. 208 breeding pairs in 2013 . Without a doubt this is because the countries concerned have implemented numerous conservation or precautionary measures for the sake of the species. In spite of this positive trend, the species is threatened mainly by increasing cases of illegal activities, such as poisoning, shooting or nest robbing. Collisions with power lines causing injuries or death also occur; however, the situation has been continuously improving due to excellent cooperation from energy companies.

V krajinách Višegrádskeho regiónu sa vyskytuje významná čast' európskej populácie orla král’ovského. Tento druh pravidelne hniezdi v Mad'arsku, na Slovensku a v Českej republike. V Pol'sku je hodnotený ako vagrantný druh. Populácia vykazuje v posledných rokoch rastúci trend. V období 2008-2013 sa zvýšila o asi 145 \%, z približne 140 hniezdiacich párov v roku 2008 na asi 208 párov v roku 2013. Je bez pochybností, že príčinou je aj to, že príslušné 
krajiny začali realizovat' početné opatrenia na zachovanie druhu. Napriek pozitívnemu populačnému trendu je druh ohrozený predovšetkým nárastom prípadov nelegálnych aktivít, ako sú otravy, ilegálne zástrely alebo vykrádanie hniezd. Kolízie s elektrickými vedeniami tiež spôsobujú zranenia alebo úhyny, situácia sa však neustále zlepšuje vd’aka vynikajúcej spolupráci zo strany energetických spoločností.

Jozef Chavko, Lucia Deutschová, Raptor Protection of Slovakia, Kuklovská 5, 84104 Bratislava, Slovakia. E-mail: chavko@dravce.sk, deutschová@dravce.sk.

Márton Horváth, MME BirdLife Hungary, Költő u. 21., 1121 Budapest, Hungary. E-mail: horvath.marton@mme.hu.

David Horal, Agency for Nature Conservation and Landscape Protection of the Czech Republic, PLA Pálava Administration and Brno Regional Centre, Kotlářská 51, 60200 Brno, Czech Republic. E-mail: david.horal@seznam.cz.

\section{Population of imperial eagle in the Baikal region: variability in different areas}

Populácia orla král'ovského v Bajkalskom regióne: variabilita v rôznych oblastiach

\section{Igor FEFELOV}

The eastern part of eastern imperial eagle range in Russia forms a population, that is of about $500 \mathrm{~km}$ distance from the western population. In the last decades, the eastern population has undergone a rapid decline in the middle of 20th century, unlike the western population. The northwesternmost part of the population in Irkutsk Region with extrazonal steppe elements and river valleys, is stable but small. Controversially, populations of Angara and Lake Baikal steppes in Irkutsk Region are rapidly declining and the breeding population has disappeared from the Olkhon Island. The small population in the Tunka valley (SW Buryatia) is typical with unusual nesting habitat in case of some pairs using poplar trees and dry trees not typical for the region where most pairs prefer nesting on live pines and larches. Preferences of nesting habitats are influenced by the tree species composition around food-abundant areas. The subpopulation in S Buryatia is reported as more successful, however, discussed to be overestimated in number of breeding pairs. In Chita Region, the situation is not good either. Generally, the size of the population of the Baikal region seems to be declining - many areas with suitable habitat and food sources can be found here, but without the occurence of eagle. According to the last mentioned fact it is not possible to extrapolate the number of imperial eagles for wide territory of the region using only data on suitable habitats. One of the reasons of negative trend of population might be the changes of wintering habitats in S China and neigbouring areas as the conditions on breeding territories are stable and the breeding success of known pairs is also favourable with 1.1-1.7 fledglings per successful nesting. However, the situation of imperial eagle population in this region seems to be vary in different parts of the breeding area as well as in other areas where the species occurs.

Východná čast' areálu orla král'ovského v Rusku tvorí populáciu, vzdialenú od západných častí $500 \mathrm{~km}$. V posledných desat'ročiach populácia $\mathrm{v}$ porovnaní so západnou klesala $\mathrm{v}$ polovici 20. storočia. Severozápadná čast' populácie je v Irkutskom regióne, ktorý je chrakteristický extrazonálnymi stepnými prvkami a údoliami riek, je stabilná ale malá. Naopak, subpopulácie v stepiach okolo Angary a jazera Bajkal v Irkutskom kraji silne klesajú, orly z ostrova Olchon úplne vymizli. Malé subpopulácie v údolí Tunka (JZ Burjatsko) sa vyznačujú neobvyklými hniezdnymi stanovištiami niektorých párov, sú to napr. topole a suché stromy, netypické pre tento región, kde orly zvyčajne využivajú živé borovice a smrekovce; populáciu ovplyvňuje zloženie stromov v oblastiach bohatých na potravu. Subpopulácia v južnom Burjatsku sa hodnotí ako lokálne úspešná, diskutuje sa však, že jej početnost' je nadhodnotená. V oblasti Čita nie je situácia priaznivá. Všeobecne platí, že počet orlov v Bajkalskom regióne naozaj klesá napriek dostatku lokalít s vyhovujúcim prostredím a dostatkom koristi. To znemožňuje odhadnút' početnost' orlov král'ovských v širšom regióne $\mathrm{s}$ len využitím GIS prístupov, identifikujúcich vhodné stanovištia. Príčinou poklesu môžu byt' negatívne zmeny na zimoviskách v južnej Číne a okolí, podmienky na hniezdiskách sú stabilné, reprodukčná úspešnost' existujúcich hniezdnych párov je dobrá (1.1-1.7 mlád’at na úspešné hniezdenie). Zdá sa teda, že situácia v tejto populácii je rôzna $\mathrm{v}$ rôznych častiach hniezdneho regiónu, ako aj v ostatných oblastiach, ktoré druh využíva.

Igor Fefelov, Research Institute of Biology at Irkutsk State University, Lenina 3, 664003 Irkutsk, Russia. E-mail: fefelov@inbox.ru. 


\section{Identifying the home range of breeding pairs of eastern imperial eagle (Aquila heliaca heliaca) through radio- tracking in Bulgaria}

Určenie domovského okrsku hniezdiacich párov orla král'ovského (Aquila heliaca heliaca) v Bulharsku pomocou rádiovej telemetrie

\section{Gradimir GRADEV, Pavlin ZHELEV \& Simeon MARIN}

The study on the home range of two breeding pairs of the eastern imperial eagle (Aquila heliaca heliaca Savigny, 1809) was implemented in 2010 and 2011 by the Green Balkans team. Two juvenile individuals were tagged with radio transmitters before fledging. These two birds formed two different pairs occupying territories in the area of the Dervent Heights Mts. and the region lying to the north of the Dervent Heights Mts. One of the tracked birds was a male individual; it was the first imperial eagle tagged with a transmitter in the country. The radio transmitter was mounted on the bird in 2007, when the eagle was at the age of about 60 days. In 2010, the male individual formed a new pair and occupied an artificial nest constructed by Green Balkans to support the breeding of the imperial eagles. The tracking of the radio-tagged bird continued in 2010 and 2011. The pair involving the tracked individual bred successfully in both years. The other tracked bird was tagged with a radio transmitter in 2008, also at the age of about 60 days. In 2011 it formed a new pair and started breeding. Despite the long incubation period, the breeding attempt failed. The results achieved through these efforts allowed the home range of breeding imperial eagles in the country to be identified for the first time. The study was carried out within a project funded by OP "Environment 2007-2013", financed by the Regional Development Fund of the European Union and the state budget of the Republic of Bulgaria.

Štúdium domovského okrsku dvoch hniezdiacich párov orla král’ovského (Aquila heliaca heliaca Savigny, 1809), realizovala v rokoch 2010 a 2011 organizácia Green Balkans. Vysielačkami boli označené dve mlád’atá v období pred vyletením z hniezda. Tieto dva jedince tvoria dva rôzne páry v oblasti Derventskej vysočiny a v regióne severne od tejto oblasti. Označený samec bol prvým orlom král'ovským, označeným vysielačkou v Bulharsku. Jedinec bol vybavený rádiovým vysielačom v roku 2007, kedy bol orol vo veku asi 60 dní. V roku 2010 samec vytvoril nový pár, ktorý obsadil umelé hniezdo postavené členmi Green Balkans na podporu hniezdenia orlov král'ovských. Sledovanie označeného jedinca pokračovalo v rokoch 2010 a 2011. Pár s označeným jedincom úspešne v oboch rokoch hniezdil. Ďalší jedinec bol označený vysielačkou v roku 2008, tiež vo veku asi 60 dní. V roku 2011 vytvoril nový pár a začal hniezdit'. Napriek dlhej inkubácii, pokus o hniezdenie nebol úspešný. Výsledky, dosiahnuté týmito snahami umožnili prvýkrát v krajine identifikáciu domovských okrskov hniezdiacich orlov královských. Štúdia bola vykonaná v rámci projektu financovaného z Operačného programu "Životné prostredie" 2007-2013, financovaného z Fondu regionálneho rozvoja Európskej únie a štátneho rozpočtu Bulharskej republiky.

Corresponding author: Gradimir Gradev, Green Balkans - Stara Zagora NGO, Skopie Str. 1, 4004 Plovdiv, Bulgaria. E-mail: ggradev@greenbalkans.org.

\section{Population surveys of eastern imperial eagles in Anatolia between 2009 and 2013}

Prieskumy populácie orla král’ovského v Anatólii v období 2009 až 2013

\section{Márton HORVÁTH, István BÉRES, Tibor JUHÁSZ, András KLESZÓ, András KOVÁCS \& Jose TAVARES}

MME BirdLife Hungary has been carrying out a five-year survey of eastern imperial eagles (Aquila heliaca) in the Anatolian parts of Turkey in the scope of a contract with The Royal Society for the Protection of Birds (RSPB) and Doga Dernegi (BirdLife Turkey), and with the Save the Raptors LIFE project of the Bulgarian Society for the Protection of Birds (BSPB). No precise data about the status of the species in Anatolia was available prior to these surveys, and only a couple of archive breeding locations were known by conservation or scientific organizations. Employees and volunteers of MME spent 5-10 days in both April and July in the selected regions of Anatolia to search for new breeding sites and to control the breeding success of the pairs found. The surveys covered the regions 
of Bolu, Eskisehir, Ankara, Corum and Cankiri. During the 60 field days the survey teams located almost 100 new imperial eagle nests in at least 50 imperial eagle territories. The breeding success was low in comparison with the Central European populations (less than 1 fledgling per nesting pair). Based on preliminary analyses, the main prey of the breeding eagles were poultry (taken both from carcass dumps and caught alive), hedgehogs and mole rats, but many other prey species in low numbers were recorded. Based on the survey results, we can conclude that Anatolia has a much larger role in the conservation of imperial eagles than we previously thought, and it may very well hold the largest populations of the species in the world after Russia and Kazakhstan.

Organizácia MME BirdLife Mad’arsko vykonávala v rámci zmluvy s Král'ovskou spoločnost’ou pre ochranu vtáctva (RSPB) a Doga Dernegi (BirdLife Turecko) a v rámci LIFE projektu „Save the Raptors“ Bulharskej spoločnosti pre ochranu vtáctva (BSPB) pätročný prieskum orlov král'ovských (Aquila heliaca) v Anatolskej časti Turecka. Pred vykonaním týchto prieskumov neboli z oblasti k dispozícii žiadne presnejšie údaje o stave druhu, ochranárske alebo vedecké organizácie poznali len niekol'ko historických hniezdnych lokalít. Zamestnanci a dobrovol'níci z MME strávili vždy v apríli a júli 5-10 dní vo vybraných regiónoch Anatólie s ciel'om vyhl'adávat' nové hniezdne lokality a kontrolovat' úspešnost' hniezdenia. Prieskum zahŕňal regióny Bolu, Eskisehir, Ankara, Corum a Cankiri. Počas 60 terénnych dní prieskumné tímy identifikovali takmer 100 nových hniezd orlov královských predstavujúcich minimálne 50 hniezdnych teritórií. V porovnaní s pomermi v strednej Európe bola úspešnost' hniezdenia nízka (menej ako jedno mlád’a na hniezdiaci pár). Na základe predbežnej analýzy predstavuje hlavnú korist’ hniezdiacich orlov hydina (kadávery alebo aktívne ulovené jedince), ježe a hraboše ale taktiež bolo zaznamenaných mnoho d'alších druhov koristi v nízkych počtoch. Na základe zistených údajov je možné konštatovat', že Anatolia zohráva ovel’a väčšiu úlohu pri ochrane orlov král’ovských ako sa skôr usudzovalo a dokonca sa tu môže vyskytovat' pravdepodobne najväčšia populácia druhu na svete po Rusku a Kazachstane.

Corresponding authors:

Márton Horváth, MME BirdLife Hungary, Költő u. 21., 1121 Budapest, Hungary. E-mail: horvath.marton@mme.hu.

Tibor Juhász, Hortobágy National Park Directorate, Sumen u. 2. 4024 Debrecen, Hungary. E-mail: juhaszt@hnp.hu.

András Kovács, Koszorú u. 46, 3300 Eger, Hungary. E-mail: andras.kovacs.ecol@gmail.com

Status of the eastern imperial eagle in Hungary between 2009 and 2013

Stav orla král'ovského v Mad’arsku v období 2009 až 2013

\section{Márton HORVÁTH, Imre FATÉR, Gábor FIRMÁNSZKY, Tibor JUHÁSZ, Antal KLÉBERT, Ádám PONGRÁCZ, Balázs SZELÉNYI \& Miklós VÁCZI}

The Hungarian population of the eastern imperial eagle (Aquila heliaca) increased by more than 50\% from 2008 (90-100 breeding pairs) to 2013 (150-160 pairs). The distribution area also expanded, by approx. $50 \mathrm{~km}$ to the south, especially in Csongrád, Békés and Bács-Kiskun counties. In parallel, the breeding density also increased in the core areas of the breeding range, especially in Jász-Nagykun-Szolnok County, which has become the most important stronghold of the species in the Pannonian Basin. Breeding success did not change significantly in comparison with the average over the previous 25-year period (1.1 fledgling/nesting pair). The prevalence of previously known important mortality factors (electrocution, collision with vehicles and shooting) did not change significantly. Meanwhile the illegal poisoning of imperial eagles, which was first reported in 2005 in Hungary, became enormously high, as more than 70 specimens were found poisoned by 2013. Probably as a result of this new significant threat, the increase of the Hungarian population over the past three decades has recently been slowed down and even stopped. Therefore, the most crucial task for the maintenance of the population in Hungary and neighbouring countries is to drastically decrease the prevalence of poisoning. For this aim MME BirdLife Hungary and its eight partner organizations have started a five-year LIFE project (HELICON, www.imperialeagle.hu) with the financial support of the European Union. Among the 33 different activities of the project, important new techniques, such as widespread satellite tracking and a poison searching dog unit, are being used to find and arrest the perpetrators in cooperation with the National Bureau of Investigation and local police. In parallel, intensive 
cooperation has begun with hunting associations to find effective alternative legal methods for controlling huntable predator species (especially fox, crow and magpie) and also for developing natural habitats in the agricultural landscape to increase the populations of primary small game (hare and pheasant) and protected bird species.

Mad'arská populácia orla král'ovského (Aquila heliaca) narástla od roku 2008 (90-100 hniezdiacich párov) do roku 2013 (150-160 párov) o viac ako 50 \%. Areál sa rozšíril o asi 50 km južným smerom najmä župách Csongrád, Békés a Bács-Kiskun. Spoločne s tým rástla aj hniezdna hustota v klúčových hniezdnych oblastiach, najmä v oblasti JászNagykun-Szolnok, ktorá sa stala najvýznamnejšou oblast'ou druhu v Panónskej panve. Hniezdna úspešnost' sa výrazne nezmenila $\mathrm{v}$ porovnaní s priemerom za predchádzajúcich 25 rokov $(1,1 \mathrm{mlád} a /$ hniezdiaci pár). Prevalencia predtým známych dôležitých faktorov mortality (úhyny na elektrickom vedení, kolízie s vozidlami a odstrel) sa významne nezmenila. Avšak nelegálne otravy orlov král’ovských, prvýkrát zaznamenané v Mad'arsku v roku 2005, nesmierne vzrástli, v roku 2013 sa zistilo viac ako 70 otrávených jedincov. Pravdepodobne v dôsledku efektu tejto novej hrozby sa tri desat'ročia trvajúci nárast mad’arskej populácie spomalil a nedávno dokonca zastavil. Pre udržanie populácie $\mathrm{v}$ Mad’arsku a v susedných krajinách je preto najdôležitejšiou úlohou dôsledne znižovat' ohrozenie otravami. Za týmto účelom MME/ BirdLife Mad'arsko spoločne s ôsmimi partnerskými organizáciami zahájili s finančnou podporou Európskej únie pätročný LIFE projekt (HELICON, www.imperialeagle.hu). V rámci 33 rôznych aktivít projektu sa využije niekol'ko nových postupov, napríklad satelitné sledovanie druhu a alebo použitie psov na vyhl'adávanie otrávených návnad s ciel’om nájdenia a zatknutia páchatel'ov v spolupráci s Národným úradom pre vyšetrovanie a s miestnymi velitel'stvami polície. Paralelne sa začala intenzívna spolupráca s pol’ovníckymi združeniami s ciel’om nájst' účinné alternatívne právne metódy pre kontrolu pol’ovných predátorov (najmä líška, vrana a straka) a tiež s ciel'om podpory tvorby prirodzených biotopov v pol'nohospodárskej krajine pre zvýšenie populácie drobnej zveri (zajac a bažant) a chránených druhov vtákov .

Corresponding authors:

Márton Horváth, Imre Fatér, MME BirdLife Hungary, Költő u. 21., 1121 Budapest, Hungary. E-mail: horvath.marton@mme.hu, fater.imre@mme.hu.

Tibor Juhász, Hortobágy National Park Directorate, Sumen u. 2, 4024 Debrecen. E-mail: juhaszt@hnp.hu.

\section{Dispersal movements of immature eastern imperial eagles in Hungary between 2011 and 2013}

Disperzné pohyby mladých orlov král’ovských v Mad'arsku v rokoch 2011 až 2013

\section{Márton HORVÁTH, Mátyás PROMMER, István LOTÁR MOLNÁR, Imre FATÉR \& Tibor JUHÁSZ}

A total of 28 eastern imperial eagles (Aquila heliaca) were tagged with GPS transmitters in Hungary between 2009 and 2013, and these tags provided more than 30,000 GPS locations till September 2013. Most of the tagged birds (23) were juveniles, but three second-calendar year immature and two adult birds were also tagged. The juvenile and immature birds showed remarkable dispersal movements, but they very rarely left the Pannonian Basin, and only two birds showed typical migration movements. One bird (called Gabi) migrated through the Balkan Peninsula, flew $500 \mathrm{~km}$ from Greece over the Mediterranean sea to Tunisia in November 2012, then crossed the Sahara in 3 weeks and settled in Ghana for wintering. In January 2013 its transmitter malfunctioned, but afterwards the bird has been observed continuously on Pantelleria Island (close to Tunisia) from April to September 2013. The other migrating bird (Krisztian) crossed the Balkan, the Bosporus and Anatolia in three weeks in October 2012, but unfortunately was electrocuted at the Syrian-Turkish border zone in November 2012. The other juvenile and immature birds spent most of their time in temporary settlement areas in south-eastern Hungary, especially in those regions which were rich in their primary prey species (hare, hamster, pheasant and mallards) and which had not high density of local breeding imperial eagle population. Based on recently available data only $30 \%$ of the tagged juveniles lived for more than one year. The reasons for mortality were the following: poisoning (4), electrocution (2), collision with train (1), unknown (2). The adult birds spent most of their time in their breeding territory, but unexpectedly made quite frequently 30-100 km long loops, in which they travelled through several other breeding territories. 
Celkom bolo v Mad'arsku v rokoch 2009 až 2013 označených GPS vysielačkami 28 orlov král’ovských (Aquila heliaca), ktoré poskytli do septembra 2013 viac ako 30000 GPS lokácií. Väčšina označených vtákov (23) boli mlád’atá, tri boli mladé vtáky v druhom kalendárnom roku života a dva boli dospelé vtáky. Mladé vtáky preukázali významné pohniezdne pohyby, ale len vel'mi zriedka opustili Panónsku panvu, len dva vtáky preukázali typické migračné správanie. Jeden vták (Gabi) migroval na Balkánsky polostrov, v novembri 2012 preletel 500 km z Grécka cez Stredozemné more do Tuniska, potom za tri týždne prekonal Saharu a na prezimovanie sa usadil v Ghane. V januári 2013 mal jeho vysielač poruchu ale vták bol pozorovaný na ostrove Pantelleria pri Tunisku od apríla do septembra 2013. Ďalší migrujúci vták (Krisztian) prekonal v októbri 2012 za tri týždne Balkán, Bospor a Anatóliu, bohužial’ v novembri 2012 bol usmrtený elektrickým prúdom v hraničnej oblasti Sýria - Turecko. Ostatné mladé vtáky strávili väčšinu času v prechodne osídlených oblastiach v juhovýchodnom Mad’arsku, najmä v oblastiach bohatých na základné druhy koristi (zajac, škrečok, bažant a kačice) a zároveň s nízkou denzitou miestnej populácie orlov královských. Na základe dostupných údajov len 30 \% označených mladých jedincov prežije viac ako jeden rok. Dôvodom mortality boli otravy (4), elektrický prúd (2), kolízia s vlakom (1) a neznáme príčiny (2). Dospelé vtáky strávili väčšinu času v hniezdnom teritóriu ale nečakane a celkom často robili aj 30-100 km dlhé okruhy, prelietavajúc cez iné hniezdne teritóriá.

Corresponding authors:

Márton Horváth, Imre Fatér, MME BirdLife Hungary, Költő u. 21., 1121 Budapest, Hungary. E-mail: horvath.marton@mme.hu, fater.imre@mme.hu.

Mátyás Prommer, Bükk National Park Directorate, Sánc u. 6., 3304 Eger, Hungary. E-mail: mprommer@yahoo.com.

Tibor Juhász, Hortobágy National Park Directorate, Sumen u. 2, 4024 Debrecen. E-mail: juhaszt@hnp.hu.

Imperial eagle in Russia and Kazakhstan: monitoring results 2008-2013

Orol král'ovský v Rusku a v Kazachstane: výsledky monitoringu 2008-2013

\section{Igor KARYAKIN, Rinur BEKMANSUROV \& Elvira NIKOLENKO}

Most of the imperial eagle breeding range lies within the arid zones of Kazakhstan and Russia. The number of imperial eagles in Russia and in Kazakhstan as of 2013 is estimated at 6,401-7,787 breeding pairs. In the following, after administrative region name, the known breeding territories in 2008-2013, the estimated number of breeding pairs and the trend for five years are given in parentheses: Nizhniy Novgorod district $(0,0-2,-1)$, Republic of Mordovia $(8,12-16,0)$, Republic of Chuvashia $(2,4-6,0)$, Penza district $(0,1-4, ?)$, Kirov district $(0,0-2,0)$, Republic of Tatarstan $(125,140-160,0)$, Ulyanovsk district $(111,120-130,0)$, Samara district $(116,120-140,0)$, Saratov district (26, 110-120, 0), Volgograd district $(61,90-110,+1)$, Astrakhan district (3, 10-30, ?), Rostov district (2, 3-6, ?), Republic of Kalmykia (5, 10-15, ?), Krasnodarskiy region and Republic of Adygeya (0, 1-5, ?), Stavropolskiy region $(18,25-35,+1)$, Republic of Karachaevo-Cherkessia $(15,60-80,+1)$, Republic of Kabardino-Balkaria (18, 100-120, +1), Republic of Severnaya Osetia (0, 1-10, ?), Republic of Chechnya (0, 1-10, ?), Republic of Dagestan $(23,50-100,+1)$, Orenburg district $(74,200-250,0)$, Republic of Bashkortostan (296, 400-430, 0), Republic of Udmurtia $(0,0-3,-1)$, Perm district $(2,4-6,-1)$, Sverdlovsk district $(2,7-9,-1)$, Chelyabinsk district $(158,190-210,0)$, Kurgan district $(37,70-90,0)$, Tumen district $(4,10-20,0)$, Omsk district $(0,1-5$, ?), Novosibirsk district $(2,3-10$, ?), Kemerovo district (0, 0-2, 0), Altai region (151, 460-490, 0), Republic of Altai (281, 430-510, 0), Krasnoyarskiy region (18, 90-120, 0), Republic of Khakassia (95, 190-220, 0), Republic of Tyva (2, 5-10, +1), Irkutsk district (12, 96-112, 0), Republic of Burjatia (14, 150-176, 0), Zabaikalskiy region $(5,17-23,0)$, Russia $(1,686,3,181-3,797)$, Western-Kazakhstan (Oralsk) district (87, 850-950, 0), Atyrau district (13, 60-120, +1), Mangistau district (19, $50-70,0)$.

Väčšina areálu orla královského leží v suchých oblastach Kazachstanu a Ruska. Počet jedincov tohto orla v Rusku a v Kazachstane sa k 2013 odhaduje na 6401 až 7787 hniezdnych párov. V nasledujúcom prehl'ade je po názve oblasti v zátvorkách uvedený počet hniezdnych teritórií v rokoch 2008-2013, odhadovaný počet hniezdiacich párov a trend vývoja po dobu piatich rokov: Nižný Novgorod $(0,0-2,-1)$, Mordvianska republika $(8,12-16,0)$, Cuvašská republika $(2,4-6,0)$, okres Penza $(0,1-4$, ?), okres Kirov $(0,0-2,0)$, Tatársko $(125,140-160,0)$, okres Uljanovsk 
(111, 120-130, 0), okres Samara (116, 120-140, 0), okres Saratov $(26,110-120,0)$, okres Volgograd $(61,90-110,+1)$, okres Astrachán (3, 10-30, ?), okres Rostov (2, 3-6, ?), Kalmycká republika (5, 10-15, ?), Krasnodarský kraj a Adygejská republika $(0,1-5$, ?), Stavropolský kraj $(18,25-35,+1)$, Karačajsko-čerkeská republika $(15,60-80,+1)$, Kabardsko-balkarská republika $(18,100-120,+1)$, Severoosetská republika $(0,1-10$, ?), Čečenská republika $(0,1-10$, ?), Dagestanská republika (23, 50-100, +1), okres Orenburg (74, 200-250, 0), Baškirská republika (296, 400-430, 0), Udmurtská republika $(0,0-3,-1)$, okres Perm $(2,4-6,-1)$, okres Sverdlovsk $(2,7-9,-1)$, okres Čeljabinsk (158, 190-210, 0), okres Kurgan (37, 70-90, 0), okres Tumen (4, 10-20, 0), okres Omsk (0, 1-5, ?), okres Novosibirsk (2 , 3-10, ?), okres Kemerovo (0 , 0-2, 0), Altajský kraj (151 , 460-490, 0), Altajská republika (281, 430-510, 0), Krasnojarský kraj $(18,90-120,0)$, Chakaská republika $(95,190-220,0)$, Tuvianska republika $(2,5-10,1)$, okres Irkutsk (12, 96-112, 0), Buriatska republika (14, 150-176, 0), Zabajkalský kraj (5, 17-23, 0), Rusko (1686, 3181-3797), okres Západný Kazachstan (Oralsk) (87, 850-950, 0), okres Atyrau (13, 60-120, +1), okres Mangistau (19, 50-70, 0).

Igor Karyakin, Russian Raptor Research and Conservation Network, Korolenko str. 17a-17, 603000 Nizhniy Novgorod, Russia. E-mail: ikar_research@mail.ru.

Rinur Bekmansurov, Russian Raptor Research and Conservation Network, Balan str. 8, 423600 Elabuga, Tatarstan Republic, Russia. E-mail: rinur@yandex.ru.

Elvira Nikolenko, Russian Raptor Research and Conservation Network, Rogacheva str. 20a-51, 633009 Berdsk, Novosibirsk region, Russia. E-mail: elnik2007@ya.ru.

Satellite tracking of the eastern imperial eagle Aquila heliaca in Hungary between 2003 and 2009

Satelitná telemetria orla král'ovského Aquila heliaca v Mad’arsku v období 2003 až 2009

\section{András KOVÁCS, Bernd-Ulrich MEYBURG, Christiane MEYBURG, Iván DEMETER, Márton HORVÁTH, János BAGYURA \& Imre FATÉR}

The eastern imperial eagle is thought to be resident or a partial migrant within the Carpathian Basin. The first $1<$ sample-size satellite tracking project of eastern imperial eagles in Hungary was carried out between 2003 and 2009 when nine juvenile eastern imperial eagles were tagged and satellite-tracked in the frame of a LIFE Nature project. Before 2003, there only limited information was available on the dispersion dynamics and migration behaviour of the species, mainly through scarce ring recoveries. The collected satellite data suggest individual variation in dispersal. Juvenile birds left the natal territory between three and eight weeks post-fledging within the period of early September and early October. The majority of tagged birds stayed within the Carpathian Basin during winter. Only two specimens dispersed over $700 \mathrm{~km}$. A single juvenile migrated to south-east reaching south-west Turkey. A geographical separation of dispersal areas could be observed in juveniles tagged in western and eastern Hungary. Tagged eagles returned to their natal territory time after time and visited other territories in the region; they were assumed to be testing their occupancy. The distribution pattern of satellite fixes revealed new breeding pairs of the eastern imperial eagle. Some of the birds returned to previous wintering areas in subsequent years, and they preferred to stay in areas with high small-game densities. Data showed the significant role of small-game releasing farms in the survival of juvenile eagles, as two major farms attracted tagged eagles from $80 \mathrm{~km}$ in eastern Hungary. Juvenile and immature eastern imperial eagles often shared their roosts and foraged with white-tailed eagles of the same age groups during the winter. The period between tagging and losing transmitter signals ranged between 35 and 1,443 days. One rehabilitated and released specimen reached its 5 th calendar year but did not occupy a territory.

Orol král'ovský je v podmienkach Panónskej panvy považovaný za stály alebo čiastočne migrujúci druh. Počas prvého projektu satelitného sledovania orlov král'ovských v Mad'arsku 1< vzorkou v rokoch 2003 až 2009 bolo sledovaných devät' mladých orlov v rámci projektu LIFE. Pred rokom 2003 bolo k dispozícii len obmedzené množstvo informácií o dynamike disperzie a o migračnom správaní sa druhu, najmä na základe spätných hlásení z krúžkovania. Získané satelitné dáta ukazujú individuálne rozdiely v disperzii. Mladé vtáky opúšt’ali hniezdnu oblast' tri až osem týždňov po vyletení v období od začiatku septembra a októbra. Väčšina označených vtákov zostala $\mathrm{v}$ zime v Panónskej panve. Len dva jedince preleteli viac ako 700 km. Jedno mlád’a migrovalo juhovýchodne až do juhozápad- 
ného Turecka. U mlád’at, označených v západnej a vo východnej časti Mad’arska je možné pozorovat' geografické oddelenie oblastí disperzie. Označené orly sa vracali do hniezdnej oblasti sporadicky, navštevovali d’alšie územia v regióne, ktoré pravdepodobne testovali pre obsadenie. Charakteristiky satelitných údajov odhalili nové hniezdne páry orlov král'ovských. Niektoré vtáky sa vrátili na tie isté zimoviská aj v nasledujúcich rokoch a preferovali pobyt v oblastiach $\mathrm{s}$ vysokou hustotou drobnej zveri. Dáta ukázali významnú úlohu malých fariem vo východnom Mad’arsku, ktoré atrahovali označené orly až zo vzdialenosti $80 \mathrm{~km}$. Mladé orly sa v zime často delili o úkryty a lovili spoločne s orliakmi morskými rovnakých vekových skupín. Čas od označenia do straty signálu vysielača bol v rozsahu 35 až 1443 dní. Jeden rehabilitovaný a vypustený jedinec sa dožil 5. kalendárneho roka ale neobsadil žiadne hniezdne územie.

Corresponding authors:

András Kovács, Koszorú u. 46, 3300 Eger, Hungary. E-mail: andras.kovacs.ecol@gmail.com.

Márton Horváth, János Bagyura, Imnre Fatér, MME BirdLife Hungary, Költő u. 21., H1121 Budapest, Hungary. E-mail: horvath.marton@mme.hu, bagyurajanos@invitel.hu, fater.imre@mme.hu.

Estimating the turnover rate of breeding eastern imperial eagles by visual identification of individuals

Odhad podielu výmien hniezdiacich orlov král'ovských pomocou vizuálnej identifikácie jedincov

\section{Bedřich LANDSFELD \& Jiř́ PAVELKA}

The authors provide a long-term overview of three nesting pairs of imperial eagles in the time period of 36,12 and 9 years in order to estimate the turnover rate of breeding individuals, exchange of nests and nesting trees. Observation of the exchange of individuals was based on the recognition of specific individuals based on the colour variability of the eagles. The analysis was done in two steps: initially on the basis of visual observation and later through the evaluation of photographic shots, especially considering the development of digital technology. The changing of individuals during the study period achieved an average value of 6.875 years per individual, with replacement of the nest every 1.51 years. In both characteristics large individual differences were observed. The replacement of individuals between different pairs is presented by the authors in two cases. There was a significant change in the preferences of nesting trees recorded by the pair observed for the longest time period. They originally preferred beeches (Fagus sylvatica) but preferred larch (Picea abies), spruce (Larix decidua) and pine (Pinus nigra) in recent years.

Autori poskytujú dlhodobý prehl'ad troch hniezdiacich párov orlov královských v časovom období 36, 12 a 9 rokov z pohl'adu rýchlosti výmeny hniezdiacich jedincov, výmeny hniezd a hniezdnych stromov. Pozorovanie výmeny jedincov bolo založené na rozoznávaní jedincov na základe ich farebnej variability. Analýza bola vykonaná v dvoch krokoch: najprv na základe vizuálneho pozorovania a neskôr na základe vyhodnotenia fotografických záberov najmä s ohl'adom na rozvoj digitálnych technológií. Výmena jedincov v priebehu sledovaného obdobia dosiahla priemerné hodnoty 6,875 rokov na jedinca s výmenou hniezda za 1,51 rokov. V oboch parametroch boli zistené vel'ké individuálne rozdiely. Zámena jedincov medzi rozdielnymi pármi bola autormi zistená v dvoch prípadoch. Došlo tiež k výraznej zmene v preferenciách hniezdnych stromov sledovaného páru. Pôvodne preferované buky (Fagus sylvatica) nahradili v posledných rokoch jedle (Picea abies), smrekovce (Larix decidua) a borovice (Pinus nigra).

Corresponding author: Bedřich Landsfeld, Raptor Protection of Slovakia, Kuklovská 5, 84104 Bratislava, Slovakia. E.mail: landsfeld@arimex.cz.

Status of the imperial eagle Aquila heliaca in Macedonia between 2004 and 2013

Stav orla král’ovského Aquila heliaca v Macedónsku v období 2004 až 2013

\section{Emanuel LISICHANETS}

In Macedonia between the years 2004 to 2013, research, monitoring and conservation activities on the imperial eagle significantly increased. The total Macedonian population is estimated to be between 20 to 25 pairs, and 23 nest sites 
were discovered. Most of the areas important for breeding are located along the central steppe part of Macedonia called "Ovce pole" (15 nests) and in the Vardar river valley from the cities of Veles to Demir Kapija ( 8 nests). The majority of the territories are located in areas of elevation between 150 and $300 \mathrm{~m}$. Almost seventy percent of the nests discovered were in poplar trees; others were on high-voltage pylons and oaks. The adult birds are mainly sedentary, spending the winter in the breeding territories. The wintering and temporary settlement areas important for immature birds were identified. The main threats to imperial eagles in Macedonia are: the cutting of poplar trees, abandonment of pastures, poisoning and electrocution.

Výskum, monitoring a ochrana orlov král'ovských sa v Macedónsku v rokoch 2004-2013 výrazne rozšíril. Celková macedónska populácia je odhadovaná na 20 až 25 párov, zistilo sa 23 hniezdísk. Väčšina dôležitých hniezdnych oblastí sa nachádza pozdĺž centrálnej stepnej časti Macedónska nazývanej "Ovce pole" (15 hniezd) a v oblasti údolia rieky Vardar od miest Veles do Demir Kapija ( 8 hniezd). Väčšina teritórií leží v oblastiach s nadmorskou výškou 150 až 300 metrov. Takmer $70 \%$ hniezd sa zistilo na topol’och, ostatné sú na vysokonapät’ových elektrických stožiaroch a duboch. Dospelé vtáky sú prevažne stále, trávia zimu v hniezdnych oblastiach. Boli identifikované zimoviská a dočasné osídlené oblasti dôležité pre mladé vtáky. Medzi hlavné hrozby orlov král’ovských $\mathrm{v}$ Macedónsku patrí výrub topol’ov, zanedbávanie pastvín, otravy a úmrtia po zásahu elektrickým prúdom.

Emanuel Lisichanets, Nature Conservation Association - AQUILA Macedonia, Belasica 3, 1430 Kavadarci, Macedonia. E-mail: e.lisichanets@gmail.com.

\section{Imperial eagle (Aquila heliaca) in Serbia \\ Orol král'ovský (Aquila heliaca) v Srbsku}

\section{Nikola STOJNIC}

In the period 2005-2013, the breeding population of the imperial eagle (Aquila heliaca) in Serbia was 2-5 pairs. The main breeding area is Fruska Gora, a forested "islet" mountain located in the Pannonian Basin, with 2-3 pairs. This is the only area in Serbia with a constant presence of nesting birds. The nests on Fruska Gora are deep in the forests, on high trees, close to young forest. The eagles hunt in surrounding lowlands. Each of the three pairs is closely connected with sousliks (Spermophillus citellus). Since 2009, one reproductive pair has been present in steppe lowlands, close to the Hungarian border. There are two nests, both on isolated solitary trees, alternately used for breeding. Among possible breeding sites, the most important is in the Danube valley, close to border with Romania, where two adults and young were observed in late summer 2012. The most frequently hunted prey is sousliks (Spermophillus citellus), followed by feral pigeons (Columba livia domestica), ravens (Corvus corax), brown hares (Lepus europaeus), long-eared owls (Asio otus) and rooks (Corvus frugilegus). Occasionally, foxes (Vulpes vulpes), moles (Talpa europaea), magpies (Pica pica), wild boar (Sus scrofa), hedgehogs (Erinaceus concolor) and Hermann's tortoises (Testudo hermanni) are registered among the prey. There is a raptor winter feeding site on Fruska Gora, regularly visited by up to two birds. No direct human threats to breeding pairs have been registered. The most probable cause of unsuccessful breeding was cold, rainy weather in May and June. Indirect human influence is habitat loss, mainly through the destruction of pastures inhabited by sousliks. In the non-breeding period, mortality caused by traffic and shooting is recorded. Conservation measures implemented are active and legal protection of breeding and hunting sites, the posture of artificial nests, winter feeding and raising awareness.

V období 2005-2013 mala hniezdna populácia orla král'ovského (Aquila heliaca) v Srbsku 2-5 párov. Hlavná hniezdna oblast' je Fruska gora, zalesnený "ostrovček" v Panónskej panve s výskytom 2-3 párov. To je jediná oblast' v Srbsku so stálou prítomnost’ou hniezdiacich vtákov. Hniezda na Fruska Gora sú hlboko v lesoch na vysokých stromoch a v blízkosti mladého lesa. Orly lovia v okolitých nížinách. Každý z troch párov je viazaný na výskyt sysl’ov (Spermophillus citellus). Od roku 2009 je jeden hniezdiaci pár prítomný v stepných nížinách v blízkosti hraníc s Mad’arskom. K dis- 
pozícii tu má dve hniezda na izolovaných solitérnych stromoch, alternatívne využívaných na hniezdenie. Medzi možnými hniezdnymi oblast’ami je najdôležitejšie údolie Dunaja v blízkosti hraníc s Rumunskom, kde boli pozorované dva dospelé a jedno mlád’a v neskorom lete 2012. Orly najčastejšie lovia sysle (Spermophillus citellus), za nimi sú ferálne holuby (Columba livia domestica), krkavce (Corvus corax), zajace pol'né (Lepus europaeus), myšiarky ušaté (Asio otus) a havrany (Corvus frugilegus). Občas sú medzi korist’ou registrované líška (Vulpes vulpes), krt (Talpa europaea), straka (Pica pica), sviňa divá (Sus scrofa), jež (Erinaceus concolor) a korytnačka zelenkastá (Testudo hermanni). Na Fruška Gora sa nachádza zimné lovisko, pravidelne navštevované dvoma vtákmi. Priame l’udské hrozby na hniezdne páry neboli registrované. Pravdepodobnou príčinou neúspešného hniezdenia sú zima, dažde v máji a v júni. Nepriamym vplyvom je strata stanovíšt', najmä ničenie pastvín obývaných sysl’ami. V období mimo hniezdenia bola zaznamenaná úmrtnost' spôsobená dopravou a strel'bou. Ochranárske opatrenia zahŕňajú aktívnu a právnu ochranu hniezdisk a lovísk, umelé hniezda, zimné prikrmovanie a zvyšovanie povedomia verejnosti.

Nikola Stojnic, Institute for Nature Conservation of Vojvodina Province, Terazije 3/V, 11000 Beograd, Serbia. E-mail: nikola.stojnic@pzzp.rs.

\section{Fifteen years of conservation of the imperial eagle in Austria}

Pätnást' rokov ochrany orla král'ovského v Rakúsku

\section{Gábor WICHMANN}

In 1999 the imperial eagle Aquila heliaca celebrated his comeback in Austria after being extinct for nearly 200 years, as the last proved breeding attempt occurred in 1811. During the past few years the population has increased slowly but continuously, and by 2013 the population consisted of 7-11 breeding pairs breeding in Burgenland and Lower Austria. Several other immature pairs are also around every year. At the beginning of the resettlement the main habitats of the eagles were agricultural steppe areas holding a high proportion of set-asides. Nowadays, however, breeding pairs are also found in areas with a low number of set-asides. One of the main drivers seems to be the accessibility of prey. The most common prey species are hare Lepus europaeus, pheasant Phasianus colchicus, hamster Cricetus cricetus and feral pigeon Columba livia forma domestica. The eagles' comeback was also encouraged by conservation measures implemented across the border in Hungary and Slovakia as well as by the widespread supply of market set-asides and the implementation of agri-environmental programmes. A conservation project together with RPS in Lower Austria is focusing inter alia on monitoring the population of imperial eagles, securing eyries and providing artificial nests as well as on informing the public, particularly those who use the land. This EU project, called CORO-SKAT, will also provide detailed conservation measures for the imperial eagle to be hopefully implemented in the coming period of Rural Development. Long-term strategies for habitat protection will have to compensate for the negative effects of the abolition of market-induced set-asides in 2008 and the growing intensification of farming. Beside the improvement in habitat quality and the safeguarding of the amount of game species, protecting against illegal persecution will be of crucial importance. The results of telemetry are showing that illegal persecution is one of the main threats to the species.

V roku 1999 orol královský Aquila heliaca oslávil svoj návrat do Rakúska po tom ako tu vyhynul pred takmer 200 rokmi, k poslednému pokusu o hniezdenie došlo v roku 1811. V posledných rokoch sa populácia pomaly ale trvale zvyšovala, v roku 2013 populáciu tvorí 7-11 hniezdnych párov v Burgenlande a v Dolnom Rakúsku. Ďalšie nedospelé páry je možné pozorovat' každý rok. Na začiatku znovuosídl’ovania tvorili hlavné biotopy orlov pol'nohospodárske stepné oblasti s vysokým podielom úhorov. V súčasnosti sa však hniezdne páry vyskytujú aj v oblastiach s malým podielom opustenej pôdy. Jednou z hlavných príčin tejto zmeny je dostupnost' koristi. Najčastejšie druhy koristi sú zajac pol'ný Lepus europaeus, bažant Phasianus colchicus, škrečok Cricetus cricetus a ferálny holub Columba livia forma domestica. Návrat orlov bol podporený opatreniami na zachovanie realizovanými v Mad'arsku a na Slovensku ako aj podporou trhu prostredníctvom agroenvironmentálnych programov. Spoločný ochranársky projekt spolu s Ochranou dravcov na Slovensku v Dolnom Rakúsku sa okrem iného zame- 
riava na sledovanie populácie orlov král'ovských, ochranu hniezd a budovanie umelých hniezd ako aj na informovanie verejnosti najmä užívatel'ov pôdy. Tento projekt EÚ s názvom CORO-SKAT poskytne aj plán podrobných opatrení pre orly král'ovské s ciel’om realizácie v nadchádzajúcom období rozvoja vidieka. Dlhodobá stratégia ochrany biotopov bude musiet' nahradit' negatívne účinky zrušenia trhových podmienok vyvolaných v roku 2008 a rastúca intenzifikácia pol'nohospodárstva. Zásadný význam bude okrem zlepšenia kvality biotopov a ochrany malých druhov zveri mat boj proti nezákonnému prenasledovaniu. Výsledky telemetrie orlov ukazujú, že nezákonné prenasledovanie je jedným z hlavných hrozieb pre tento druh.

Gábor Wichmann, Birdlife Austria, Museumplatz 1/10/8, 1070 Vienna, Austria. E-mail: gabor.wichmann@birdlife.at. 